EKONOMI POLITIK INSTITUSI ZAKAT: SATU PENELITIAN TERHADAP INSTITUSI ZAKAT DI PULAU PINANG

Mohammad Najwa

PRAKTIK KURBAN ONLINE DALAM PERSPEKTIF ISLAM TEBAR HEWAN KURBAN THK DI DOMPET DHUAFA

Reni Noviati

WAKAF SAHAM DITINJAU DARI HUKUM ISLAM DAN PERATURAN PERUNDANGUNDANGAN SETELAH BERLAKUNYA UNDANG-UNDANG NOMOR 41

TAHUN 2004 TENTANG WAKAF

Gusva Havita dan Gestivia Hakim

KARAKTERISTIK ENTREPRENEUR SYARIAH PADA USAHA MIKRO, KECIL, DAN MENENGAH (UMKM) DI BOGOR

Siti Usniah dan Anas Alhifni

ALTERNATIF SOLUSI ATAS PROBLEMATIKA PEMBIAYAAN MUDHARABAH

Rafidah

FAKTOR-FAKTOR YANG MEMPENGARUHI MOTIVASI MAHASISWA MENJADI ENTREPRENEUR SYARIAH

Nur Maulida Hidayat dan Anas Alhifni 
Ketua Editor :

Tuti Kurnia, SP., M.Si

Editor Pelaksana :

H. Sofian Muhlisin, LLB., LLM

Furqonul Haq, SEI., M.EI

Journal Manager :

Wildan Munawar, SEI

Jurnal Syarikah: Jurnal Ekonomi Islam adalah jurnal ilmiah yang diterbitkan untuk mendukung pengembangan ekonomi Islam. Jurnal Syarikah akan memuat artikelartikel yang terkait dengan kajian ekonomi Islam baik kajian teoritis maupun praktis. Redaksi menerima sumbangan artikel, tulisan ilmiah dari para peminat ilmiah kajian ekonomi dan keuangan syariah. Proses editing seperlunya tanpa mengubah maksud dan kandungan tulisan tersebut.

Alamat Redaksi :

Fakultas Ekonomi Islam

Universitas Djuanda Bogor

Gedung B Lantai 4

Jl. Tol Ciawi No.1 Ciawi Bogor Kode Pos 16720

Telp. (0251) 8240985

Email : fei@unida.ac.id 


\section{DAFTAR ISI}

EKONOMI POLITIK INSTITUSI ZAKAT: SATU PENELITIAN TERHADAP INSTITUSI ZAKAT DI PULAU PINANG

Mohammad Najwa

PRAKTIK KURBAN ONLINE DALAM PERSPEKTIF ISLAM TEBAR HEWAN KURBAN THK DI DOMPET DHUAFA

Reni Noviati

WAKAF SAHAM DITINJAU DARI HUKUM ISLAM DAN PERATURAN PERUNDANG-UNDANGAN SETELAH BERLAKUNYA UNDANG-UNDANG NOMOR 41 TAHUN 2004 TENTANG WAKAF

Gusva Havita, Gestivia Hakim

KARAKTERISTIK ENTREPRENEUR SYARIAH PADA USAHA MIKRO, KECIL DAN MENENGAH (UMKM) DI BOGOR

Siti Usniah, Anas Alhifni

ALTERNATIF SOLUSI ATAS PROBLEMATIKA PEMBIAYAAN MUDHARABAH

Rafidah

FAKTOR-FAKTOR YANG MEMPENGARUHI MOTIVASI MAHASISWA MENJADI ENTREPRENEUR SYARIAH

Nur Maulida Hidayat, Anas Alhifni 


\title{
PRAKTIK KURBAN ONLINE DALAM PERSPEKTIF ISLAM TEBAR HEWAN KURBAN THK DI DOMPET DHUAFA
}

\section{THE PRACTICE OF KURBAN ONLINE IN THE PERSPECTIVE OF ISLAM IN TEBAR HEWAN KURBAN THK DOMPET DHUAFA}

\author{
R. Noviati1a \\ 1aProgram Studi Ekonomi Islam Fakultas Ekonomi Islam Universitas Djuanda, Jl. Tol Ciawi \\ No. 1, Kotak Pos 35 Bogor 16720.
}

\begin{abstract}
This research aims to determine what is the mechanism practice of kurban online in the institution of THK Dompet Dhuafa and compliance with rule in Islamic jurisprudence. The research method used descriptive qualitative method. The results of this study demonstrate the mechanism practice of kurban online through THK Dompet Dhuafa starting from ordering, choosing, paying, checking the quality and quantity, distribution, until to verification (documentation) with payment can be done directly (at the counter THK) and indirectly (website and online shopping sites). The implementation of THK Dompet Dhuafa use wakalah and salam contracts. The practice of sacrifice was accordance with Islamic jurisprudence, because pillars and terms/requirements are met.
\end{abstract}

Keywords: Kurban Online, THK, Dompet Dhuafa.

\begin{abstract}
ABSTRAK
Penelitian ini bertujuan untuk mengetahui bagaimana mekanisme praktik kurban online yang ada di THK Dompet Dhuafa dan kesesuaiannya dengan aturan dalam fiqih Islam. Metode penelitian menggunakan metode penelitian deskriptif kualitatif. Hasil penelitian ini menunjukkan mekanisme praktik kurban online melalui THK Dompet Dhuafa dimulai dari memesan, memilih, membayar, pengecekan kualitas dan kuantitas, penyaluran, hingga pembuktian (dokumentasi) dengan pembayaran yang dapat dilakukan secara langsung (di konter THK) dan secara tidak langsung (website atau situs belanja online). Pelaksanaan THK Dompet Dhuafa menggunakan akad wakalah dan salam. Praktik kurban tersebut telah sesuai dengan fiqih Islam, karena rukun dan syaratnya sudah terpenuhi.
\end{abstract}

Kata kunci: Kurban Online, THK, Dompet Dhuafa.

Noviati, Reni. 2017. Praktik Kurban Online Dalam Perspektif Islam Tebar Hewan Kurban Di Dompet Dhuafa . Jurnal Syarikah 3 (1): 343 - 357

\section{PENDAHULUAN}

Kurban merupakan salah satu ibadah yang Allah SWT cintai, yang dilakukan pada hari raya Idul 'Adha dan dilaksanakan dengan sungguh-sungguh sesuai dengan syariat Islam. Orang Islam (muslim) yang melaksanakan ibadah kurban akan mendapatkan manfaat (fadhilah), salah 
satu fadhilahnya adalah hewan kurban akan mendatangi orang yang mengurbankannya di hari kiamat dan akan menjadi kendaraannya (Lailah, 1999: 55). Allah SWT telah menyebutkan dengan jelas perintah dan keutamaan berkurban dalam firmanNya:

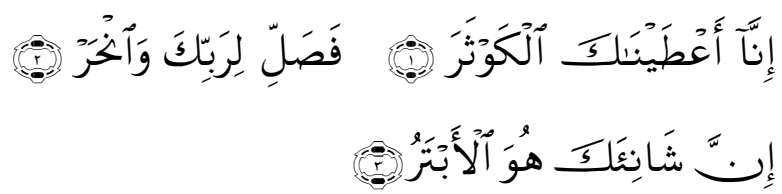

Artinya: "Sesungguhnya Kami telah memberikan kepadamu nikmat yang banyak. Maka dirikanlah shalat karena Tuhanmu, dan berkorbanlah. Sesungguhnya orang-orang yang membenci kamu Dialah yang terputus" (QS. Al-Kautsar: 1-3).

Adapun maksud dari kata berkurban dalam dalam firman Allah SWT di atas adalah menyembelih hewan kurban dan mensyukuri nikmat karena telah Allah beri nikmat yang banyak, agar hambahambanya selalu bersyukur dan tidak kufur (mengingkari) nikmat yang telah Allah berikan kepada hamba-hambanya.

Fenomena perkembangan praktik Ibadah kurban dari tahun ke tahun mengalami peningkatan dan kemudahan dalam pelaksanaannya, disebabkan dengan berkembangnya ilmu pengetahuan dan teknologi (IPTEK) yang semakin canggih. Salah satu hasil dari perkembangan IPTEK yang sangat berperan dalam pelaksanaan ibadah kurban adalah internet.

Keberadaan internet sangat diperlukan karena kebutuhan masyarakat dalam kemudahan akses dan pelayanan selalu ingin terpenuhi, maka dari itu kemudian menyebabkan adanya praktik ibadah kurban yang berbasis internet yang saat ini dikenal dengan sebutan kurban online (Sitorus, 2015: 1; Romdhon, 2015: 6).

Berdasarkan dengan adanya perkembangan IPTEK ini kemudian bermunculan lembaga-lembaga keuangan dan lembaga NIRLABA yang kemudian menyediakan jasa praktik ibadah kurban secara online tersebut. Pengguna jasa program kurban online kebanyakan berasal dari kalangan menengah ke atas dan memang masyarakat perkotaan yang tergolong sibuk sehingga tidak sempat mengurus proses ibadah kurbannya dan atau bagi pekurban yang ingin kurbannya tersalurkan ke daerah-daerah lain selain tempat dia tinggal (menetap).

Pelaksanaan praktik ibadah kurban online yang telah dilaksanakan selama ini ternyata masih banyak masyarakat yang belum mengetahui bagaimana mekanismenya, bahkan tidak sedikit dari kalangan akademisi yang telah mengetahui dengan jelas apa itu praktik kurban online dan bagaimana pelaksanaannya.

Berdasarkan pengelolaan yang telah dilakukan salah satu lembaga nirlaba yang ada di daerah Jakarta, dalam pelaksanaannya menyediakan jasa praktik ibadah kurban online ini memuat atau menggunakan akad-akad dalam ekonomi Islam. Akad-akad ekonomi Islam yang digunakan dalam praktik kurban online di lembaga nirlaba tersebut adalah akad wakalah dan akad salam.

\section{MATERI DAN METODE}

\section{Tinjauan Fikih Tentang Transaksi (Jual Beli) Online}

Majelis Ulama Indonesia (MUI) maupun Dewan Syariah Nasional (DSN) memang belum ada mengeluarkan fatwa yang khusus mengatur tentang transaksi/perdagangan secara elektronik (online) atau yang kita kenal dengan istilah e-commerce, tetapi dalam fiqih kontemporer ada beberapa fatwa yang terkait dengan kegiatan tersebut.

\section{Pengertian E-commerce}

Transaksi perdagangan elektronik (elektronic commerce/e-commerce) adalah jual beli yang kegiatan penyebaran, pembelian, penjualan, pemasaran barang dan jasanya dilakukan dilakukan sistem elektronik (internet, televisi, website, atau jaringan komputer lainnya). Sedangkan menurut Microsoft Encarta dalam Languyu, 
e-commerce adalah perdagangan barang dan jasa dengan bantuan internet atau jaringan dengan komputer lain (Husaini, 2014: 189; Languyu, 2015: 94).

\section{Mekanisme E-commerce}

E-commerce dalam transaksinya juga mempunyai hal-hal yang harus dilakukan dan dipenuhi, kegiatan atau hal-hal yang harus dilakukan ketika melakukan transaksi e-commerce antara lain (Muttaqin, 2010: 463-465):

a. Penawaran/akad transaksi

Penawaran dalam transaksi ecommerce biasanya dilakukan oleh penjual dengan memasang iklan atau penawaran melalui internet (website atau media sosial), penawaran yang dilakukan sudah menampilkan jenis barang, harga, dan spesifikasi lainnya yang menjelaskan tentang barang yang ditawarkan tersebut. Jadi akad penawaran akan terjadi ketika seseorang menggunakan internet atau media sosial lain untuk melihat iklan dan memesan barang yang ia inginkan baik via email atau chatting dengan kontak yang telah disediakan oleh pihak penjual.

b. Objek akad

Setiap transaksi jual beli sudah pasti harus ada barang/hal yang diperjual belikan baik itu berupa barang ataupun jasa, begitu juga dengan objek yang ada pada transaksi e-commerce. Barang/jasa (objek akad) dalam transaksi e-commerce diperbolehkan atau tidaknya tergantung pada aturan-aturan yang ditetapkan oleh negara di mana transaksi itu dilakukan, sedangkan di Indonesia sendiri mengharuskan penjual menawarkan objek (barang/jasa) yang dibolehkan dalam undang-undang (tidak rusak, cacat atau ada cacat yang tersembunyi), agar layak untuk diperjual belikan.

c. Pembayaran

Pembayaran dalam transaksi ecommerce biasanya tidak ada penangguhan pembayaran ketika setelah terjadinya akad, karena dapat menyebabkan transaksi menjadi batal/rusak, kecuali telah terjadi kesepakatan bahwa pembayaran dapat dilakukan dalam beberapa waktu (berangsur). Proses pembayaran dalam ecommerce dapat dilakukan secara langsung dan secara tidak langsung. Pembayaran secara langsung di sini dapat dilakukan langsung oleh kedua belah pihak tanpa adanya perantara, sedangkan pembayaran yang tidak langsung dapat dilakukan melalui Automatic Teller Machine (ATM) dengan melibatkan institusi keuangan (finansial) dan pemegang akun yang akan melakukan pengiriman uangnya dari akun masing-masing. Kemudian bentuk pembayaran secara tidak langsung yang lain adalah dengan adanya perantara (pihak ketiga), seperti pembayaran dengan debet, kartu kredit, dan cek masuk.

d. Pengiriman

Pengiriman merupakan kegiatan dalam mekanisme e-commerce yang dilakukan setelah pembeli membayar atas barang yang dibelinya dari penjual. Pengiriman barang menjadi hal yang hampir terjadi dalam segala proses penyerahan barangnya, karena dalam transaksi $e$ commerce penjual dan pembeli tidak tinggal berdekatan. Waktu yang digunakan untuk pengiriman tergantung seberapa jauh jarak, lama tempuh dan kebijakan dari pihak ketiga sebagai pengirim (penjual).

e. Penerimaan

Serah terima (penerimaan barang) dalam transaksi e-commerce tidak memerlukan tempat khusus untuk penyerahan barangnya, karena posisi penjual dan pembeli yang tidak berdekatan jaraknya (jauh) menjadikan barang tidak langsung diterima oleh pembeli ketika diberikan oleh penjual (dikirim terlebih dahulu). Dapat dikatakan apabila tempat tersebut disepakati oleh kedua belah pihak dan cukup mewakili (representatif), maka dapat dijadikan dasar sebagai tempat serah terima barang.

\section{Ketentuan dan Dasar Hukum $E$ - commerce dalam Islam}

Setiap kegiatan yang dilakukan oleh suatu lembaga maupun perorangan pasti mempunyai landasan hukum dalam operasionalnya, baik dari segi hukum Islam maupun hukum positifnya. Transaksi $e$ - 
commerce yang termasuk dalam transaksi ekonomi juga menggunakan kaidah fiqih muamalah. Kaidah fiqih digunakan dalam mengidentifikasi transaksi ekonomi, karena kegiatan ekonomi juga merupakan salah satu aspek muamalah dari sistem ekonomi Islam. Adapun kaidah fiqih muamalahnya:

"hukum asal dalam urusan muamalah adalah boleh, kecuali ada dalil yang mengharamkannya".

Kaidah tesebut menjelaskan bahwa segala sesuatu dalam muamalah boleh dilakukan, karena memang pada dasar/ hukum awalnya diperbolehkan sampai ada nash shahih yang melarangnya atau ada yang bertentangan dengan prinsip muamalah dalam Islam. Kaidah muamalah ini juga berdasarkan firman Allah SWT:

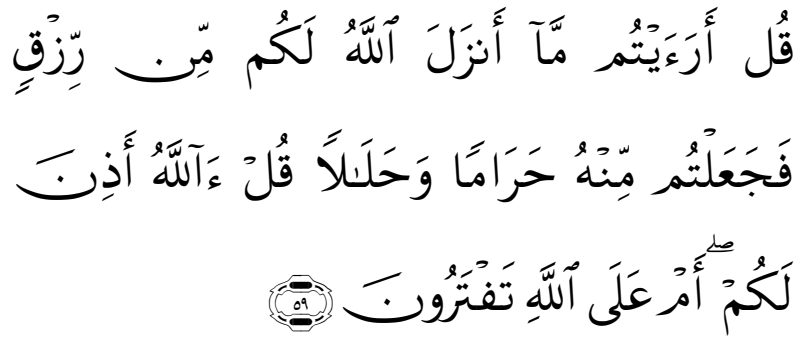

Artinya: Katakanlah "Terangkanlah kepadaku tentang rezki yang diturunkan Allah kepadamu, lalu kamu jadikan sebagiannya haram dan (sebagiannya) halal". Katakanlah "apakah Allah telah memberikan izin kepadamu (tentang ini) atau kamu mengada-adakan saja terhadap Allah" (QS. Yunus, 10: 59).

Kaidah fiqih muamalah ini menjelaskan bahwa semua hal yang berhubungan dengan dengan muamalah, dan tidak ada ketentuan (larangan atau anjuran) yang berdasarkan dalil syari'at Islam (Al-Qur'an maupun Al-Hadits) maka hal tersebut diperbolehkan dalam Islam.

\section{Kurban Online}

Kurban online merupakan salah satu program yang disediakan oleh beberapa lembaga keuangan dan lembaga nirlaba seperti Dompet Dhuafa (DD) yang berorientasi untuk kemudahan-kemudahan bagi masyarakat yang ingin melaksanakan praktik ibadah kurbannya.

Jasa praktik kurban online yang dilakukan oleh lembaga nirlaba DD yang saat ini dikenal dengan program Tebar Hewan Kurban (THK), di THK sendiri Pekurban yang ingin melaksanakan ibadah kurbannya cukup dengan memesan dan memilih hewan kurbannya melalui internet atau dapat langsung memesan di konterkonter yang telah disediakan oleh THK di mall, swalayan dan pusat perbelanjaan yang lain.

\section{Penelitian Terdahulu}

Penelitian terdahulu yang dijadikan rujukan oleh peneliti adalah penelitian yang dilakukan oleh Rohmiatin Faizah, seorang mahasiswi Fakultas Syariah dan Hukum di Universitas Islam Negeri Sunan Kalijaga Yogyakarta, dengan judul penelitian "Praktek Arisan Kurban dalam Tinjauan Hukum Islam dan Hukum Adat Pada Jama'ah Masjid Al-Munawwaroh Desa Bubutan Kecamatan Purwodadi Kabupaten Purworejo".

Penelitian ini menggunakan metode deskriptif analitic yang berusaha untuk memaparkan fakta-fakta yang ada yang berkaitan dengan pelaksanaan arisan kurban, kemudian menghasilkan kesimpulan pada penelitiannya bahwa dalam pelaksanaan arisan kurban yang terjadi di lapangan telah terpenuhi rukun, akad, dan syarat sahnya dalam melakukan praktik arisan tersebut (Faizah, 2014: 1618).

Penelitian terdahulu lainnya yang peneliti jadikan rujukan adalah penelitian yang dilakukan oleh Retnowulan dan Hermani dengan judul "Tinjauan Hukum Jual Beli Secara Online" dengan pendekatan yang berdasarkan pada ketentuan perundang-undangan yang berlaku dan kaitannya dengan permasalahan yang dibahas, yaitu Undang-undang No. 11 Tahun 2008 tentang Informasi dan Elektronik.

Sumber hukum yang dipakai dalam penelitian tersebut adalah sumber hukum primer (Undang-undang No. 11 Tahun 
2008 dan Kitab Undang-undang Hukum Perdana) dan sekunder (buku-buku literatur serta artikel-artikel yang berkaitan dengan pokok permasalahan). Penelitian ini mendapatkan kesimpulan bahwa dokumen elektronik merupakan alat bukti sah yang diakui oleh hukum secara perdata, selama peraturan perundang-undangan tidak mengatur secara khusus bahwa transaksi harus dibuat secara tertulis (Retnowulan dan Regina, 2010: 19-30).

\section{Pendekatan dan Jenis Penelitian}

Jenis penelitian yang digunakan dalam penelitian dalam penelitian ini adalah penelitian deskriptif kualitatif dengan pendekatan studi pustaka, sedangkan metode penelitian yang digunakan adalah fenomenologi.

Fenomenologi digunakan karena metode ini dapat menjelaskan dari fenomena yang terjadi apakah dari suatu kejadian tersebut dapat memberikan makna ataupun tidak baik bagi individu maupun masyarakat dengan mengumpulkan data-data melalui wawancara kepada sejumlah individu atau objek penelitian untuk dikaitkan dengan prinsip-prinsip (Hasbiansyah, 2008: 170).

\section{Objek dan Subjek Penelitian}

Objek dari penelitian ini adalah program kurban online yang disediakan oleh Tebar Hewan Kurban (THK) yang ada di lembaga nirlaba Dompet Dhuafa (DD), sedangkan subjek dalam penelitian ini adalah peneliti sendiri.

\section{Populasi dan Sampel}

Populasi yang ditetapkan dalam penelitian ini adalah beberapa lembaga yang telah melaksanakan atau menyediakan jasa praktik ibadah kurban secara online (Baitul Maal Hidayatullah melalui Kurban Berkah Nasional (KBN) dan Program Tebar Hewan Kurban (THK) yang ada di Lembaga Nirlaba Dompet Dhuafa).

Sampel yang diambil dalam penelitian ini adalah program Tebar Hewan Kurban (THK) yang ada di lembaga Dompet Dhuafa
(DD), pendapat para ahli tentang fikih ibadah terkait ibadah kurban dan masyarakat yang pernah melaksanakan ibadah kurbannya melalui program ini.

Teknik pengambilan sampel yang digunakan adalah teknik sampling purposive, di mana ketika akan menentukan sampelnya dilakukan berbagai pertimbangan tertentu karena sampel yang diambil harus benar-benar mewakili apa yang dibutuhkan dalam penelitian ini.

\section{Jenis dan Sumber Data}

\section{Data Primer dan Sekunder}

Data primer merupakan data pokok yang menjadi sumber dalam penelitian, data ini dapat diperoleh melalui wawancara dan alat-alat memperoleh data yang lain. Penelitian ini memperoleh data primernya dari hasil wawancara, observasi dan dokumentasi (Arikunto, 2010: 145).

Data sekunder merupakan data yang digunakan sebagai data pendukung suatu penelitian untuk menguatkan kebenaran dari suatu data tersebut. Data sekunder dalam penelitian ini berasal dari jurnal, buku-buku, internet dan beberapa literatur lain yang ada hubungannya dengan penelitian terkait mekanisme praktik kurban online yang ada di THK Dompet Dhuafa (Arikunto, 2010: 157).

\section{Teknik Pengumpulan Data}

Teknik pengumpulan merupakan salah satu langkah yang harus dilakukan saat melakukan penelitian, dan pada tahap ini diharuskan untuk dapat menentukan dengan benar akan menggunakan cara/teknik apa yang harus digunakan untuk memperoleh data dalam penelitian. Adapun teknik pengumpulan data yang dipakai dalam penelitian ini antara lain: wawancara, observasi dan dokumentasi (Denzin. Lincoln, 2009: 499).

Teknik wawancara yang digunakan dalam penelitian ini adalah wawancara semi terstruktur, di mana dari awal penelitian (pra penelitian) sudah berusaha mendapatkan informasi walaupun belum menggunakan pedoman wawancara yang tersusun secara lengkap dan sistematis 
pada setiap wawancara yang dilakukan. Kemudian pada saat akan melakukan penelitian yang lebih mendalam barulah melakukan wawancara dengan menggunakan pedoman yang tersusun secara sistematis.

Observasi yang digunakan dalam penelitian ini adalah observasi nonpartisipan. Jenis observasi ini dipakai karena subjek penelitian (peneliti) yang melakukan penelitian tidak terlibat secara langsung dengan objek penelitian (praktik kurban online yang ada di THK Dompet Dhuafa).

Dokumentasi yang digunakan dalam penelitian ini adalah dengan mengambil gambar-gambar yang diperlukan terkait dengan praktik kurban online tersebut, gambar-gambar yang diperlukan dalam penelitian ini diperoleh dari berbagai media, seperti website program THK Dompet Dhuafa, internet, dan foto-foto atau data-data yang diberikan langsung oleh THK Dompet Dhuafa.

\section{Teknik Analisis Data}

Teknik analisis data adalah cara peneliti untuk menganalisis data untuk penelitiannya, dimulai dari menyediakan data, mengorganisasikan data, memilahmilah data menjadi satuan yang dapat dikelola, mencari apa yang diperlukan dan penting untuk dipelajari, serta memilahmilah uraian yang terbagi-bagi agar dapat ditangkap dengan jelas maksud dari permasalahan yang akan diteliti (Moleong, 2013: 248; Komariah, 2009: 97).

Teknik analisis data yang digunakan dalam penelitian ini adalah teknik analisis data dengan metode fenomenologi yang berdasarkan pemikiran Van Kaam, adapun teknik analisis data yang dilakukan oleh Van Kaam meliputi enam langkah, antara lain: Horizontaling data yang telah diperoleh (mengumpulkan data dari berbagai sumber, sudut pandang, pernyataan-pernyataan terkait penelitian, serta data-data lain yang memiliki nilai sama dan dapat mendukung penelitian), membuat daftar makna dari data-data yang diperoleh, mengelompokkan data ke dalam kelompok-kelompok atau tema-tema tertentu agar tidak terjadi penjelasan yang tumpang tindih dan berulang, membuat penjelasan yang tekstural, membuat penjelasan yang terstruktural, serta menyatukan deskripsi tekstural dan terstruktural supaya mendapatkan makna dari fenomena yang ada.

\section{Tahapan-tahapan Penelitian}

Tahapan-tahapan penelitian yang dilakukan dalam penelitian ini merujuk pada pemikiran Moleong (2013) yang meliputi empat tahapan penelitian.Tahap pertama adalah tahap pra lapangan di mana sebelum terjun ke lapangan sudah menentukan fokus penelitian dengan melakukan pengamatan pada praktik kurban online melalui berbagai sumber (buku-buku, jurnal penelitian, website, dan observasi awal ke lembaga Dompet Dhuafa yang telah menyediakan jasa kurban online melalui program Tebar Hewan Kurban/THK nya).

Tahap kedua adalah tahapan kegiatan lapangan yang harus terjun ke lapangan untuk melakukan penelitian, pada tahap ini penelitian yang dilakukan fokus pada program Tebar Hewan Kurban (THK) dengan wawancara, observasi ke THK Dompet Dhuafa dan kepada para ahli fikih kurban dalam Islam.

Tahapan yang ketiga adalah tahap analisis data di mana pada tahap ini penelitian dilakukan dengan mengolah data yang diperoleh dengan wawancara, observasi, dan dokumentasi, serta menjelaskan masalah yang terkait dengan penelitian, kemudian melakukan pengecekan kebenaran data yang diperoleh dengan melakukan uji validitas, reliabillitas dan objektifitas agar terbukti keabsahan datanya.

Tahap keempat adalah tahap penulisan laporan, yang dilakukan dengan cara menyusun hasil penelitian yang telah diteliti selama dalam masa penelitiannya. Kemudian di tahapan yang terakhir ini juga dilakukan konsultasi dan bimbingan untuk 
perbaikan dan hasil penelitian yang lebih baik.

\section{HASIL DAN PEMBAHASAN}

\section{Tebar Hewan Kurban (THK)}

Program THK dimulai sejak tahun 1994, pada awalnya program ini bernama "Menebar 999 Hewan Kurban", tetapi sejak tahun 1998 namanya berubah menjadi Tebar Hewan Kurban. Cita-cita dari THK ini sebenarnya sederhana, ingin membagi hewan kurban ke daerah-daerah terpencil, agar kelezatan daging kurban tidak hanya dirasakan dan menumpuk pada masyarakat kota khususnya Jakarta.

Tahun pertama hingga ke tahun-tahun setelahnya (saat ini) program THK Dompet Dhuafa selalu mengalami perkembangan dan peningkatan baik dari jumlah pekurban yang selalu bertambah sampai dengan meningkatnya pelayanan yang disediakan oleh THK Dompet Dhuafa, walaupun dalam praktiknya THK perkembangan tersebut pernah mengalami penurunan tetapi THK Dompet Dhuafa bisa meningkatkan kembali kinerjanya dengan melihat kinerja yang telah lalu.

Adanya kurban online melalui program Tebar Hewan Kurban (THK) ini dikatakan oleh Dompet Dhuafa praktiknya lebih kepada kemudahan untuk masyarakat yang ingin melaksanakan ibadah kurban, karena pekurban (orang yang berkurban) telah merasakan manfaat dari adanya praktik kurban online ini. Melihat dari sejarah perkembangan program THK sendiri, eksistensi atau keberadaan program ini juga sudah banyak masyarakat yang percaya dengan pelayanan yang ditawarkan oleh THK Dompet Dhuafa.

Kenaikan jumlah hewan kurban ini menjadi tolak ukur bagi masyarakat maupun Dompet Dhuafa sendiri, karena ketika jumlah hewan kurban yang ditebar/disalurkan bertambah setiap tahunnya, berarti semakin bertambah jumlah pekurban (orang yang berkurban) melalui program THK Dompet Dhuafa. Praktik ibadah kurban secara online ini berarti sudah diterima oleh beberapa kalangan di masyarakat, tetapi tidak semua masyarakat sudah menerima atau bahkan mengetahui adanya praktik kurban online ini.

\section{Mekanisme Kurban Online}

Kurban online merupakan praktik ibadah kurban yang mekanisme pelaksanaannya mulai dari proses pembelian (memesan, memilih, dan membayar) hewan kurbannya, hingga proses penyaluran (pendistribusian) hewan kurbannya dilakukan secara online oleh orang yang berkurban (pekurban) dengan lembaga yang menyelenggarakan program tersebut.

Wujud hewan kurbannya ada walaupun praktiknya dilakukan secara online, tetapi dalam pelaksanaan pengadaan, penyembelihan, serta pembagian hewan kurbannya dilakukan dengan benar dan nyata oleh lembaga yang menyediakan program kurban online ini (Dompet Dhuafa, 2017).

Berikut mekanisme atau tahapantahapan dalam praktik ibadah kurban online di THk Dompet Dhuafa:

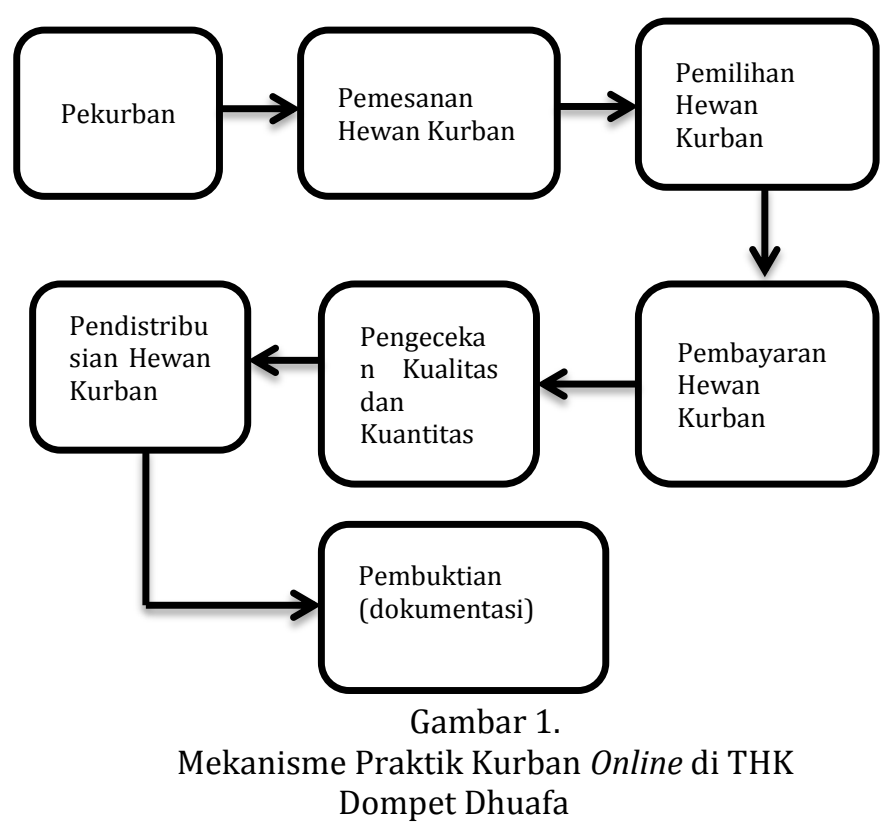

Dilihat dari gambar tentang mekanisme praktik kurban online di THK Dompet Dhuafa tersebut, dapat dijelaskan dengan terperinci dimulai dari pekurban yang ingin melaksanakan praktik ibadah 
kurbannya dengan melakukan pemesanan, pemilihan, pembayaran, pengecekan kualitas dan kuantitas, pendistribusian, hingga pembuktian (dokumentasi) untuk hewan kurbannya sebagai berikut:

\section{Pemesanan Hewan Kurban}

Tata cara dalam pelaksanaan praktik kurban online yang ada di program THK Dompet Dhuafa diawali dari pemesanan yang dilakukan oleh masyarakat (pekurban), baik yang sudah mengetahui adanya program kurban online melalui teman, kerabat, atau lewat iklan yang dipasang oleh bagian THK di internet.

Pemesanan hewan kurban tidak hanya dapat dipesan secara langsung melalui counter-counter THK yang telah Dompet Dhuafa Republika sediakan di beberapa pusat perbelanjaan (mall, carrefour, dan lain sebagainya), dengan mengisi form konfirmasi kurban tetapi bisa dipesan juga melalui website THK dan situs online seperti Tokopedia, Elevania dan lain sebagainya, karena THK sendiri melakukan kerjasama dengan situs-situs online tersebut.

\section{Pemilihan Hewan Kurban}

Pemilihan hewan kurban merupakan salah satu langkah yang dilakukan oleh pekurban di THK, untuk menentukan kurban yang diinginkannya. Adapun jenisjenis hewan kurban yang ditawarkan oleh THK adalah kambing standar, kambing standar dengan berat/bobot 23-28 Kg, kambing premium bobotnya $29-35 \mathrm{Kg}$, dan sapi yang beratnya dari 250-300 Kg. Semua proses pemilihan hewan kurban dilakukan secara online, karena sudah disediakan fitur-fiturnya oleh THK di setiap pengiklanan program kurban online ini (brosur, majalah, pamflet, situs-situs belanja online, dan website THK).

\section{Pembayaran Hewan Kurban}

Proses pembayaran pada praktik kurban online di THK dapat dilakukan secara online dan langsung di konter. Jadi pekurban yang ingin membayar secara langsung, dapat membayar secara tunai ke petugas counter yang sudah disiapkan oleh Dompet Dhuafa di pusat-pusat perbelanjaan (Mall, Carrefour, dan lain sebagainya).

Sedangkan yang ingin membayar secara online tidak perlu datang ke lembaga Dompet Dhuafa untuk membayar hewan kurbannya, karena pekurban yang ingin membayar hewan kurbannya dapat langsung mengirimkan uangnya melalui Automatic Teller Machine (ATM) ke No. Rekening yang telah disediakan oleh THK Dompet Dhuafa (Dompet Dhuafa, 2016).

\section{Pengecekan Kualitas dan Kuantitas (Quality Control)}

Proses yang paling penting dalam mekanisme praktik kurban online ini salah satunya adalah pengecekan kualitas dan kuantitas (quality control) pada hewan ternak. Proses ini dilakukan sampai tiga kali oleh THK untuk memastikan bahwa hewan-hewan ternak yang akan dibeli oleh pekurban, benar-benar pas dengan yang sudah ditentukan. Quality Control yang pertama adalah dengan melihat bagaimana pemberian makan dan pertumbuhan bobotnya, kemudian yang kedua adalah mengecek dan memperhatikan bagaimana kebersihan kandangnya, dan segala perawatan untuk kesehatannya, dan yang ketiga (terakhir) dilakukan pada waktuwaktu mendekati hari $\mathrm{H}$ berkurban ( $\mathrm{H}-3$, $\mathrm{H}-2$, dan bahkan $\mathrm{H}-1$ ) pada proses quality control yang terakhir ini THK Dompet Dhuafa akan memastikan bahwa hewanhewan tersebut bobotnya benar-benar pas dengan standar yang sudah THK tentukan. Kegiatan ini dilakukan THK Dompet Dhuafa sebagai bentuk kehati-hatian dalam menyediakan dan pelaksanaan praktik kurban online ini.

\section{Pendistribusian Hewan Kurban}

Pendistribusian hewan kurban dilakukan setelah hewan-hewan tersebut telah dibeli oleh pekurban dan sudah melalui berbagai proses yang selanjutnya akan disalurkan atau didistribusikan ke daerah-daerah, sampai pada tahun 2016 lalu sudah ada lebih dari 350.000 jiwa yang telah menerima daging kurban dari THK Dompet Dhuafa. Daerah penyebaran atau distribusi hewan kurban sudah tersalurkan 
di Indonesia dengan enam negara sahabat, 24 provinsi, 138 kabupaten/kota, 618 kecamatan, dan 2.058 desa (Dompet Dhuafa, 2016).

Daerah yang menjadi target oleh THK secara garis besar dibagi menjadi dua (2), yaitu daerah prioritas dan daerah biasa. Adapun yang termasuk dalam daerah prioritas adalah: Daerah penampungan atau pengungsian yang disebabkan bencana alam seperti banjir, kekeringan, gempa bumi dan lain sebagainya, serta kerusuhan dan tragedi sosial lainnya. Daerah-daerah yang ada di luar pulau Jawa dengan pendapatan perkapita penduduknya berada di bawah garis kemiskinan. Daerah yang mayoritas penduduknya muslim, tetapi karena ditakutkan akibat desakan ekonomi membuat akidahnya mudah berpaling.

Sedangkan daerah yang termasuk dalam kategori daerah biasa untuk pendistribusian hewan kurbannya adalah: Daerah di wilayah pulau Jawa yang masyarakat sekitarnya mampu, tetapi jarang mengeluarkan hewan kurbannya. Panti jompo yang mengurusi orang tua yang sudah tidak memiliki keluarga. Panti asuhan yang memelihara anak-anak yatim piatu dan putus sekolah dikarenakan tidak mempunyai biaya. Masjid-masjid, pesantren, dan majelis ta'lim yang berada di daerah terpencil, kemudian dalam keadaan sulit untuk mendapatkan bantuan hewan dari pekurban karena umumnya ekonomi masyarakatnya kurang mampu (Dompet Dhuafa, 2016).

Pendistribusian hewan kurban yang dilakukan oleh THK Dompet Dhuafa sangat membantu masyarakat yang tinggal di daerah yang sulit mendapatkan daging kurban, walaupun tidak semua daerah yang jauh saja penyaluran daging hewan kurbannya tetapi juga masih daerah pulau Jawa.

\section{Pembuktian}

Proses terakhir dari mekanisme praktik kurban online yang ada di THK Dompet Dhuafa adalah pembuktian, yang mana pembuktian ini harus dilakukan oleh
THK untuk memberikan bukti (rasa percaya) kepada masyarakat yang sudah berkurban melalaui program ini, bahwa praktik ibadah kurbannya telah dilaksanakan dan disalurkan dengan baik dan tepat kepada target di daerah-daerah tujuan THK.

Pembuktian ini dilakukan oleh THK dengan menghadirkan bukti-bukti praktik pelaksanaan ibadah kurban seperti fotofoto (dokumentasi) terkait dengan pelaksanaan transaksi kurban online tersebut. Dokumentasi ini juga merupakan salah satu bentuk usaha dari THK untuk memupuk kepercayaan dari masyarakat yang sudah maupun yang ingin berkurban di THK.

\section{Pihak-pihak yang Terlibat dalam Pelaksanaan Kurban Online}

Pelaksanaan praktik kurban online yang ada di THK Dompet Dhuafa melibatkan beberapa pihak dalam operasionalnya, karena THK sendiri tidak dapat terlaksana dengan baik tanpa adanya pihak-pihak tersebut.

Adapun pihak-pihak yang terlibat dalam pelaksanaan praktik kurban online ini antara lain adalah pertama, THK Dompet Dhuafa yang merupakan lembaga penyedia jasa praktik kurban online itu sendiri. Kedua, Pekurban (orang yang berkurban) yang melakukan praktik ibadah kurbannya melalui THK Dompet Dhuafa serta berperan sebagai pembeli produk (jasa kurban online) yang ditawarkan oleh THK Dompet Dhuafa. Ketiga, Mitra kurban (peternak) yang merupakan pemberdayaan masyarakat oleh THK Dompet Dhuafa dengan pemberian modal di awal. Keempat, Bank sebagai pihak yang bekerjasama juga dengan THK Dompet Dhuafa untuk hal transaksi pembayaran (transfer dana). Kelima, Provider yang merupakan penyedia jasa layanan untuk akses internet dalam pelaksanaan praktik kurban online di THK Dompet Dhuafa.

Kemudian yang terakhir adalah Situs belanja online sebagai pihak yang bekerjasama sama dengan THK untuk pengiklanan (promosi) dan sebagai media 
pemesanan oleh masyarakat yang ingin berkurban online. Dalam hal ini THK bekerjasama dengan beberapa situs belanja online, seperti Tokopedia dan Elevania (Muttaqin, 2010: 461).

\section{Kesesuaian Praktik Kurban Online THK Dompet Dhuafa dalam Aturan Fikih Islam}

Gambaran mengenai praktik kurban online yang ada di THK Dompet Dhuafa baik dari segi objek, tatacara/mekanisme, dan akadnya, praktik kurban online ini dapat dikaitkan dengan transaksi online. Sampai saat ini Majelis Ulama Indonesia (MUI) maupun Dewan Syariah Nasional (DSN) memang belum ada mengeluarkan fatwa yang khusus mengatur tentang transaksi/perdagangan secara elektronik (online) atau yang kita kenal dengan istilah e-commerce, tetapi pemerintah telah mengeluarkan peraturannya dalam Undang-undang No. 11 Tahun 2008 tentang Informasi dan Transaksi Elektronik beserta turunannya Peraturan Pemerintah Nomor 82 Tahun 2012 tentang Penyelenggaraan Sistem dan Transaksi Elektronik (Romdhon, 2015: 99).

Pemerintah merasa perlu membentuk dan menetapkan pengaturan mengenai pengelolaan informasi dan Transaksi Elektronik dikarenakan beberapa pertimbangan, salah satunya adalah pentingnya peran pemanfaatan Teknologi informasi dalam perdagangan dan pertumbuhan perekonomian nasional yang menunjang kesejahteraan masyarakat, serta sebagai sarana untuk mencegah penyalahgunaan pemanfaatan Teknologi Informasi sehingga pemerintah merasa perlu mendukung pengembangan Teknologi Informasi melalui infrastruktur hukum dan pengaturannya (Romdhon, 2015: 99-100).

Dalam fikih kontemporer ada beberapa fatwa yang telah dikeluarkan oleh MUI terkait kurban online karena teknisnya juga dilakukan secara online. Berikut skema teknis praktik kurban yang ada di THK Dompet Dhuafa beserta analisisnya:

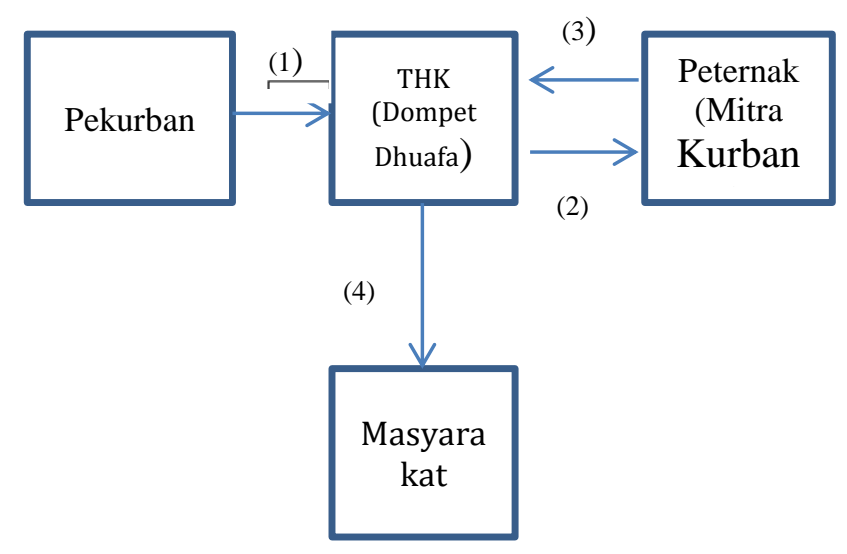

Gambar 2.

Skema Kurban Online THK Dompet Dhuafa

Keterangan:

1. Pekurban menyerahkan uang ke THK Dompet Dhuafa untuk melakukan ibadah kurbannya, di sini pekurban mewakilkan pembelian dan pembayaran hewannya kepada THK Dompet Dhuafa dengan akad wakalah.

2. THK Dompet Dhuafa sebagai wakil dari pekurban membeli hewan kurban dengan akad salam ke peternak (mitra kurban) dengan spesifikasi dan kriteria yang telah ditentukan sebelumnya dengan pekurban pada saat pekurban pekurban memesan dan memilih atau menentukan hewan kurbannya.

3. Peternak (mitra kurban) menyerahkan hewan kurban ke THK pada waktu yang telah ditentukan (disepakati bersama) oleh peternak dan THK.

4. THK mewakili pekurban dalam menyalurkan (mendistribusikan) hewan kurbannya kepada masyarakat, dan di sini menggunakan akad wakalah kembali karena masih mewakili pekurban dalam pelaksanaan ibadah kurbannya.

Berdasarkan gambar (Skema Kurban Online THK Dompet Dhuafa) dan keterangan skema kurban online THK Dompet Dhuafa dilihat dari pelaksanaan akadnya memuat akad jual beli salam dan wakalah. Kesesuaian akad salam dan wakalah pada kurban online yang ada di THK Dompet Dhuafa baik dari segi objek, tatacara/mekanisme, dan akadnya dalam fikih Islam dapat dilihat dari syarat-syarat 
dari kedua akad yang juga terdapat dalam pelaksanaan praktik kurban online.

\section{Akad Wakalah dan Akad Salam}

Berdasarkan Dewan Syariah Nasional Majelis Ulama Indonesia (DSNMUI) dalam akad wakalah harus ada pihak yang disebut dengan yang mewakilkan (muwakkil), yang mewakili (wakil), dan hal-hal yang diwakilkan. Adapun syarat-syarat muwakkil antara lain:

1. Pemilik sah yang dapat bertindak terhadap sesuatu yang diwakilkan.

2. Orang mukallaf atau anak mumayyiz dalam batas-batas tertentu, yakni dalam hal-hal yang bermanfaat baginya.

Kemudian syarat-syarat dari wakil sendiri adalah:

1. Cakap hukum.

2. Dapat mengerjakan tugas yang diwakilkan kepadanya.

3. Wakil adalah orang yang diberi amanat.

Syarat-syarat yang terakhir dari wakalah yang harus dipenuhi adalah:

1. Diketahui dengan jelas oleh orang yang mewakili.

2. Tidak bertentangan dengan syariah Islam.

3. Dapat diwakilkan menurut syariah Islam.

Berdasarkan syarat-syarat yang telah disebutkan di atas, kurban online THK Dompet Dhuafa juga telah memenuhi syarat-syarat dalam pelaksanaan akad wakalah, yaitu:

1. Ketentuan atau syarat dari pekurban (muwakkil) yang ada di THK dan kesesuaiannya dengan syarat-syarat yang ada pada akad wakalah adalah: Pertama, Muwakkil di THK merupakan pemilik sah ketika sudah membeli dari peternak (mitra kurban) tetapi melalui THK sebagai pihak yang mewakilinya (wakil). Kedua, muwakkil sudah pasti mumayyiz dan mukallaf, karena masyarakat yang ingin berkurban harus mengisi form kurban dengan keterangan diri yang sejelas-jelasnya.

2. Ketentuan atau syarat-syarat dari wakil (THK) dan kesesuaiannya dengan akad wakalah, antara lain: Pertama, THK dikenal sebagai program yang berada di lembaga yang cakap hukum, dalam artian lembaga ini legal/sah di mata hukum. Kedua, THK merupakan program yang berada di lembaga yang kompeten dalam mengerjakan tugas yang diberikan kepadanya. Kemudian yang ketiga,THK juga merupakan wakil yang benar-benar melaksanakan amanat yang diberikan oleh muwakkil (pekurban).

3. Ketentuan/syarat-syarat dari barang/hal-hal yang diwakilkan oleh muwakkil dan kesesuaiannya dengan syarat-syarat pada akad wakalah antara lain: Pertama, hal yang diwakilkan diketahui dengan jelas oleh orang yang mewakili, karena dalam hal ini THK merupakan lembaga yang melaksanakan ibadah kurban mewakili pekurban. Kedua, barang/hal-hal yang diwakilkan (dalam hal ini kurban) kepada THK bukanlah barang atau hal-hal yang bertentangan atau dilarang dalam Islam. Kemudian syarat ketiga yang telah terpenuhi oleh THK dalam akad wakalah dilihat dari ketentuan barang/hal-hal yang diwakilkan dapat diwakilkan menurut syariat Islam, karena hal yang diwakilkan ini merupakan pelaksanaan ibadah kurban yang telah sesuai dengan syariat, hanya saja pelaksanaannya diwakilkan kepada orang lain (THK).

Akad yang ada dalam praktik kurban online yang lain kemudian adalah salam, karena praktik ini dilakukan juga dengan jual beli secara pesanan. Ketentuan dan syarat yang harus dilakukan dalam akad salam meliputi ketentuan tentang pembayaran, dan ketentuan tentang barang.

Syarat-syarat dalam ketentuan tentang pembayaran tersebut antara lain adalah:

1. Alat bayar harus diketahui jumlah dan bentuknya, baik berupa uang, barang, atau manfaat.

2. Pembayaran harus dilakukan pada saat kontrak disepakati.

3. Pembayaran tidak boleh dalam bentuk pembebasan hutang. 
Ketentuan/syarat-syarat mengenai barang dalam akad salam, antara lain:

1. Barang yang dijual harus jelas ciricirinya dan dapat diakui sebagai hutang.

2. Barang yang dijual harus dapat dijelaskan spesifikasinya.

3. Penyerahan barangnya dilakukan kemudian.

4. Waktu dan tempat penyerahan barang harus ditetapkan berdasarkan kesepakatan.

5. Pembeli tidak boleh menjual barang sebelum menerimanya.

6. Tidak boleh menukar barang, kecuali dengan barang sejenis sesuai dengan kesepakatan.

Berdasarkan syarat dan ketentuan yang ada pada akad salam di atas, THK sendiri sudah memenuhi beberapa syarat yang harus dipenuhi tersebut, hanya saja ada yang sedikit berbeda dari praktik kurban online THK yang ada di Dompet Dhuafa. Adapun ketentuan dan syarat yang telah dipenuhi oleh THK untuk kesesuaian akadnya dengan akad salam, antara lain:

1. Ketentuan dan syarat dalam pembayarannya pada praktik kurban online dan kesesuaiannya dengan syaratsyarat yang telah disebutkan di atas dalam akad salam, antara lain: Pertama, alat bayar dalam pelaksanaan praktik kurban online ini sudah harus diketahui jumlahnya, baik berupa uang, barang, atau manfaat ketika di awal pemesanan pun telah ditetapkan berapa harga yang harus dibayar dan alat bayarnya (dalam hal ini uang) juga harus diketahui jumlahnya. Kedua, pembayaran harus dilakukan pada saat kontrak disepakati, karena dalam praktik kurban online telah ada prosedur tentang pembayaran ketika pekurban ingin membeli hewan kurbannya dengan kesepakatan kedua belah pihak yang telah disepakati. Kemudian yang terakhir, pembayaran dalam praktik kurban online ini bukanlah dalam bentuk untuk membebaskan hutangnya ataupun hutang orang lain, karena praktiknya murni untuk jual beli hewan kurban bukan untuk membayar hutang.

2. Ketentuan dan syarat mengenai barang dalam kurban online dan kesesuaiannya dengan syarat-syarat pada akad salam antara lain: Pertama, barang (hewan kurban) yang ditawarkan dan dijual oleh THK ciri-cirinya jelas disebutkan dalam iklan yang dibuat oleh THK dan ada penjelasan lebih secara langsung dalam website THK sendiri tentang ciri-ciri (jenis) hewan kurbannya. Kedua, spesifikasi dari hewan kurban sudah jelas, karena THK sendiri sudah mengklasifikasikan jenis hewan kurban yang ditawarkannya. Ketiga, penyerahan barang (hewan kurban) nya dilakukan kemudian karena praktik jual beli kurban online ini dilakukan dengan pemesanan terlebih dahulu. Walaupun dalam praktiknya hewan kurban yang telah dibeli oleh pekurban tidak diserahkan kepada pekurban, melainkan akan diberikan/disalurkan oleh THK kepada masyarakat di daerah lain yang lebih membutuhkan. Keempat, waktu dan tempat penyerahan hewan kurban telah disepakati oleh kedua belah pihak, hanya saja penyerahan tidak diterima langsung oleh pekurban melainkan akan disalurkan kepada masyarakat lain sebagaimana pekurban telah mengamanatkan pelaksanaannya kepada THK. Kemudian yang terakhir adalah tidak boleh menukar hewan kurban kecuali dengan hewan kurban sejenis atau pekurban menambah jumlah uang apabila menginginkan jens hewan kurban yang lebih dari jenis yang dipesannya pertama kali, karena jenisjenis dan spesifikasi hewan kurban sudah ditentukan oleh THK.

\section{KESIMPULAN DAN IMPLIKASI}

\section{Kesimpulan}

Berdasarkan hasil penelitian dan pembahsan yang dilakukan, dapat disimpulkan beberapa hal sebagai berikut:

1. Kurban online merupakan praktik ibadah kurban yang pelaksanaannya 
dimulai dari proses pembelian (memesan, memilih, dan membayar) hewan kurbannya, hingga proses penyaluran (pendistribusian) hewan kurbannya dilakukan secara online oleh orang yang berkurban (pekurban) dengan lembaga yang menyelenggarakan program tersebut. Wujud hewan kurbannya ada walaupun praktiknya dilakukan secara online, tetapi dalam pelaksanaan pengadaan, penyembelihan, serta pembagian hewan kurbannya dilakukan dengan benar dan nyata oleh lembaga yang menyediakan program kurban online ini.

2. Mekanisme pelaksanaan kurban online yang ada pada Tebar Hewan Kurban (THK) Dompet Dhuafa Republika meliputi:

a. Pemesanan hewan kurban yang dapat dilakukan secara langsung dengan mengisi form konfirmasi hewan kurban di konter-konter THK yang telah disediakan oleh Dompet Dhuafa Republika di beberapa pusat perbelanjaan, dan dapat memesan secara tidak langsung (online) melalui website THK atau melalui situs belanja online (Tokopedia dan Elevania).

b. Pemilihan hewan kurban dilakukan oleh pekurban untuk memilih apakah dia ingin berkurban jenis standar atau premium.

c. Pembayaran hewan kurban dapat dilakukan oleh pekurban dengan cara langsung membayar ke konter THK atau bisa juga dengan mengirimkan (transfer) uangnya melalui Automatic Teller Machine (ATM) ke No. Rekening yang telah disediakan oleh THK Dompet Dhuafa.

d. Pengecekan kualitas dan kuantitas (Quality Control) dalam pelaksanaan kurban online ini dilakukan untuk memastikan bobot/berat hewan kurban yang nantinya akan dikurbankan benar-benar pas, dan supaya terjaga juga kualitas dalam artian di sini kebutuhan akan kesehatan hewan kurbannya terpenuhi.

e. Pendistribusian hewan kurban yang dilakukan oleh THK Dompet Dhuafa dibagi menjadi dua daerah tujuan dalam penyebaran daging kurbannnya, yaitu daerah prioritas dan daerah biasa.

f. Pembuktian (dokumentasi) dilakukan oleh THK untuk memberikan bukti kepada masyarakat yang sudah berkurban melalui program ini, bahwa praktik ibadah kurbannya telah dilaksanakan dan disalurkan dengan baik dan tepat kepada target di daerah-daerah tujuan THK (daerah prioritas dan daerah biasa). Adapun bukti yang diperoleh pekurban terkait ibadah kurbannya melalui THK, antara lain: surat ucapan terimakasih dari penerima kurban, foto hewan kurban dan pelaksanaannya, serta majalah Tebar Hewan Kurban (THK).

3. Berdasarkan mekanisme praktik kurban online melalui THK Dompet Dhuafa Republika yang telah diterangkan sebelumnya, ada beberapa pihak yang terlibat dalam pelaksanaan kegiatannya antara lain:

a. Tebar Hewan Kurban (THK) Dompet Dhuafa yang merupakan lembaga penyedia jasa kurban online itu sendiri.

b. Orang yang berkurban (pekurban), yaitu konsumen yang ingin melakukan praktik ibadah kurbannya melalui online (THK).

c. Peternak hewan (mitra kurban), adalah masyarakat yang diberdayakan oleh Dompet Dhuafa dengan memberikan mereka modal untuk merawat dan memelihara hewan kurban selama masa hewan tersebut belum dibeli oleh pekurban.

d. Bank, sebagai pihak yang telah THK rangkul sebagai mitra untuk bekerjasama dalam hal transaksi pembayaran (transfer dana).

e. Provider, pihak yang berperan sebagai penyedia jasa layanan untuk akses 
internet dalam pelaksanaan praktik kurban online di THK.

f. Situs belanja online, sebagai pihak yang bekerjasama sama dengan THK untuk pengiklanan (promosi) dan sebagai media pemesanan oleh masyarakat yang ingin berkurban online (tokopedia, elevania, dan lain sebagainya).

4. Keberadaan kurban online yang ada saat ini belum begitu dikenal masyarakat luas, karena dari beberapa responden atau partisipan (pendapat para ahli) pun terkait tentang kurban online ini ada yang mengatakan belum tahu sama sekali tentang praktik kurban online, kemudian ada juga yang mengatakan sudah pernah mendengar istilah (kurban online) dan hanya sekedar tahu tetapi tidak mengetahui dengan pasti apa yang dimaksud dengan istilah tersebut.

5. Kesesuaian praktik kurban online dengan perspektif Islam melihat dari mekanisme atau skema, serta pihakpihak yang terlibat dalam praktik tersebut menyebabkan adanya akadakad ekonomi Islam, akad-akad tersebut adalah akad wakalah dan akad salam. Praktik THK yang ada di Dompet Dhuafa Republika telah sesuai dengan praktik akad wakalah dan akad salam, karena dalam praktiknya THK sudah memenuhi rukun dan syarat yang ada dalam akad wakalah dan akad salam.

\section{Implikasi}

Implikasi hasil penelitian dari penelitian ini adalah berdampak pada masyarakat dalam mengetahui praktik ibadah kurban online yang ada di THK Dompet Dhuafa, bagi lingkungan akademisi maupun msyarakat yang awalnya menyangsikan/meragukan bagaimana praktik dan hukumnya jadi lebih mengerti dan menerima keberadaan praktik ibadah kurban secara online ini. Kemudian dengan adanya penelitian tentang praktik kurban online ini diharapkan masyarakat akan lebih memiliki kesadaran berbagi kebahagiaan di saat hari raya Idul 'Adha berlangsung, kepada masyarakat (saudara sesama muslim) yang keberadaannya dekat maupun yang jauh dari tempat tinggal kita dengan menyalurkan kurbannya melalui THK Dompet Dhuafa.

\section{DAFTAR PUSTAKA}

Abdullah, Mulyana. 2016. Qurban: Wujud Kedekatan Seorang Hamba dengan Tuhannya. Jurnal Pendidikan Agama Islam- ta'lim Vol. 14 No. 1. Bandung.

Al-Utsaimin, M. S. 2003. Tatacara Qurban Tuntunan Nabi SAW. Terjemahan: Aris Munandar. Media Hidayah. Jogjakarta.

Arifudin, Mohammad. 2015. Kurban Kolektif Dalam Perspektif Hadits. Islamuna. Volume.2, Nomor. 1. Pamekasan.

Arikunto, Suharsimi. 2010. Prosedur Penelitian: Suatu Pendekatan Praktik. Edisi revisi. Rineka Cipta. Jakarta.

Departemen Agama RI. Al-Qur'an dan Terjemahnya. Syamil Cipta Media. Bandung.

Faizah, Rohmiatin. 2014. Praktek Arisan Qurban dalam Tinjauan Hukum Islam dan Hukum Adat Pada Jama'ah Masjid Al-Munawwaroh. Skripsi. Purworejo.

Herniwati. 2015. Penerapan Pasal 1320 Terhadap KUHPerdata Terhadap Jual Beli Secara Online (e-commerce). Jurnal IPTEKS Terapan, vol. 8, No. 4. Padang.

Husaini, M. 2014. Bisnis E-commerce dalam Perspektif Islam. Jurnal Ilmu Dakwah dan Pengem bangan Komunitas. Volume, 9. No. 2.

http://thk.dompetdhuafa.org//conversatio n. Diakses pada tanggal 16 Februari 2017. Pukul 15.43 WIB.

Komariah, DKK. 2012. Metode Penelitian Kualitatif. Alfabeta. Bandung.

K. Denzin, Norman. S. Lincoln, Yvonna. 2009. Hanbook of Qualitative Research. Pustaka Pelajar. Jogjakarta.

Lailah, Lutfi. 1999. Studi Tentang Qurban Dalam Agama-agama Samawi. Skripsi. Institut Agama Islam Negeri Sunan Ampel. Surabaya. 39-55.

Languyu, Novianto. 2015. Kedudukan Hukum Penjual dan Pembeli dalam 
Bisnis Jual Beli Online. Lex et Societatis, Vo. III, No. 9. Manado.

Moleong, New Lexy J. 2013. Metodologi Penelitian Kualitatif. Remaja Rosdakarya. Bandung.

Muttaqin, Azhar. 2010. Transaksi Ecommerce Dalam Tinjauan Hukum Jual Beli Islam. Ulumuddin, Volume VI, Tahun IV. Malang.

Retnowulan, Evi dan Hermani, Regina. 2010. Tinjauan Hukum Jual Beli Secara Online. Jurnal Hukum, Vol. XIX, No. 19. Surabaya.

Romdhon, Muhammad Rizqi. 2015. Jual Beli Online Menurut Madzhab Asy-syafi'i. Pustaka Cipasung. Jawa Barat.

Sitorus, Daniel Alfredo. 2015. Perjanjian Jual beli Melalui Internet (E-Commerce) Ditinjau Dari Aspek Hukum Perdata. Skripsi, 1. Jogjakarta.
Sugiyono. 2013. Metode Penelitian Kuantitatif, Kualitatif, dan Kombinasi (Mixed Methods). Alfabeta. Bandung.

Thousani, Dkk. 2015. Upaya Pengembangan E-Business dalam Pemasaran Produk Secara Internasional (Studi pada Akademi Bisnis Online Indonesia Surabaya). Jurnal Administrasi Bisnis (JAB) Vol. 23 No. 1. Malang, Surabaya.

Undang-undang Republik Indonesia, Nomor 11 Tahun 2008 tentang Informasi dan Transaksi Elektronik, Pasal 1 (satu) angka 1 (satu).

Wulandari, Friska Muthi. 2015. Jual Beli Onlie yang Aman dan Syar'i (Studi Terhadap Pandangan Pelaku Bisnis online di Kalangan Mahasiswa dan Alumni Fakultas Syariah dan Hukum UIN Sunan Kalijaga). Skripsi, Jogjakarta.

Yahya, M. Slamet. 2006. Strategi Pendidikan Islam Menghadapi Kemajuan IPTEK. Jurnal Insania, Vol. 11, No. 1. Purwokerto. 


\section{Ucapan Terima Kasih}

Dewan Redaksi serta Redaksi Pelaksana Jurnal Syarikah mengucapkan terima kasih dan penghargaan setinggi-tingginya kepada para pakar yang telah berperan sebagai mitra bebestari pada penerbitan Jurnal Syarikah Volume 3 Nomor 1 Juni Tahun 2017.

$$
\text { Dr. Nurul Huda, M.Si }
$$

Semoga kerjasama yang baik dapat terus berlangsung di masa-masa yang akan datang untuk lebih meningkatkan kualitas Jurnal Syarikah. 


\title{
PANDUAN BAGI PENULIS JURNAL SYARIKAH: JURNAL EKONOMI ISLAM
}

\author{
Pemutakhiran Juni 2017
}

\section{RUANG LINGKUP}

Jurnal Syarikah: Jurnal Ekonomi Islam mendorong pengembangkan ilmu pengetahuan dan teknologi dalam bidang Ekonomi Islam melalui penerbitan karya ilmiah berbasis hasil penelitian (orisinal).

\section{JENIS NASKAH}

Jenis naskah yang dipublikasikan adalah naskah orisinal hasil penelitian yang belum pernah dipublikasikan atau tidak sedang dalam proses publikasi oleh media publikasi lain dan terbebas dari plagiarisme. Bahasa publikasi adalah bahasa Indonesia atau bahasa Inggris. Setiap naskah yang masuk ke dewan redaksi akan menjalani proses peer-review.

Naskah hasil penelitian harus didasarkan atas data hasil penelitian orisinal yang belum dipublikasikan dan dianalisis menggunakan metode statistik. Naskah hasil penelitian yang disajikan secara deskriptif tanpa rancangan penelitian yang dikontrol oleh peneliti, naskah hasil penelitian yang hanya berupa pengulangan (replikasi) dari hasil penelitian yang telah dipublikasikan, misalnya hanya kondisi geografisnya yang berbeda, tidak akan dipertimbangkan untuk dipublikasikan. Naskah bernomor seri tidak dapat diterima, kecuali disampaikan dan disajikan pada waktu yang bersamaan.

\section{PENGIRIMAN NASKAH}

Naskah yang diajukan ditujukan ke Pimpinan Dewan Redaksi Jurnal Syarikah, melalui e-mail ke tuti.kurnia@unida.ac.id. Naskah dimaksud harus dilengkapi dengan Surat Pernyataan Orisinalitas dan Pemindahan Hak Publikasi yang ditandatangi oleh semua penulis.

\section{KONVENSI DAN KETAATASASAN}

Naskah harus ditulis dengan tema font Time New Roman 12, spasi ganda, batas tepi $2,5 \mathrm{~cm}$, halaman berukuran A4, menggunakan program microsoft office word. Naskah ditulis tidak lebih dari 7.500 kata berdasarkan urutan bagian berikut:

1) Judul (Title): JUDUL berbahasa Indonesia dan Inggris, Nama Penulis, Alamat Penulis, Penulis untuk Korespondensi, dan Judul Singkat (Running Head).

2) Tajuk Utama (main section headings): ABSTRACT, ABSTRAK, PENDAHULUAN, MATERI DAN METODE, HASIL, PEMBAHASAN, KESIMPULAN DAN IMPLIKASI, UCAPAN TERIMA KASIH, DAFTAR PUSTAKA.

3) Lampiran: Tabel, Grafik, dan Gambar.
Judul naskah harus berhuruf tebal dan kapital, ditulis pada bagian tengah dari baris tersendiri. Tajuk dan subtajuk ditulis pada baris tersendiri, mulai dari batas tepi kiri badan teks. Tajuk berhuruf tebal dan kapital. Subtajuk berhuruf tebal dan huruf kapitalnya hanya pada awal kata. Jarak antara tajuk dan subtajuk adalah 10 point (pt) sedangkan jarak antara tajuk atau subtajuk dan badan teks adalah 6 pt. Pembeda paragraf dimulai pada paragraf kedua setelah tajuk atau subtajuk dan dicirikan oleh baris pertamanya yang berjarak $0,5 \mathrm{~cm}$ dari batas tepi kiri badan teks.

Naskah yang terlalu panjang atau terlalu pendek akan dikembalikan kepada penulis. Sebagai pedoman, 7.500 kata setara dengan 34 halaman ukuran A4, yang ditulis dengan tema font Time New Roman 12, spasi ganda, marjin $2,5 \mathrm{~cm}$ dari semua tepi halaman. Judul tidak lebih dari 12 kata, Judul Singkat tidak lebih dari 50 karakter, Abstract dan Abstrak masing-masing tidak lebih dari 250 kata, key words dan kata kunci masing-masing 5 kata, dan Pendahuluan tidak lebih dari 500 kata.

\section{Judul}

Judul harus ringkas dan padat informasi, tidak memuat kata singkatan, dan memuat hal-hal berikut:

a) membangkitkan minat bagi pembaca yang memindai jurnal atau daftar judul jurnal.

b) Menyediakan informasi yang cukup bagi pembaca untuk menilai relevansi suatu naskah dengan minatnya

c) Memasukkan kata kunci atau frasa yang dapat digunakan dalam mengindeks dan menarik informasi tentang penelitian yang dilakukan.

d) Menghindari kata-kata yang tidak penting, seperti "suatu studi kasus ...." atau "suatu tinjauan empiris tentang ....". Hal-hal tersebut lebih tepat ditulis pada subbagian Materi dan Metode.

e) Tidak boleh memuat kata tempat, seperti “.... di Bogor"

\section{Nama dan Alamat Penulis}

Nama dan alamat penulis harus disajikan seperti contoh berikut:

G. PraditinKa ${ }^{1, a}$ dan W. munawar ${ }^{2}$

${ }^{1}$ Lembaga Penelitian dan Pengembangan Universitas Djuanda, Jl. Tol Ciawi Kotak Pos 35 Bogor 16720.

${ }^{2}$ Program Studi Ekonomi Islam Fakultas Ekonomi Islam Universitas Djuanda, Jl. Tol Ciawi No. 1 Kotak Pos 35 Bogor 16720.

aKorespondensi: Tuti Kurnia. Telepon: 0818106472; E-mail: tuti.kurnia@unida.ac.id 


\section{Judul Singkat (running head)}

Penulis harus menuliskan judul singkat tidak lebih dari 50 karakter termasuk ketukan kosong.

\section{Abstract dan Abstrak}

Abstract ditulis dalam bahasa Inggris baku secara konsisten (American English atau British English). Abstrak ditulis dalam bahasa Indonesia yang baik dan benar, menggunakan kata-kata baku. Baik abstract maupun abstrak dibuat dalam satu paragraf utuh tanpa ada acuan pustaka atau perujuk tabel dan/atau gambar, tidak lebih dari 250 kata. Isinya harus memuat masalah penting yang akan dipecahkan, tujuan, metode, hasil, kesimpulan, dan tidak boleh terlalu padat dengan angka-angka. Penyingkatan kata tidak diperkenankan kecuali kata dimaksud akan digunakan lebih dari satu kali..

\section{Keywords dan Kata Kunci}

Keywords (berbahasa Ingris) dan Kata kunci (berbahasa Indonesia), masing-masing tidak lebih dari lima kata dan sebaiknya tidak sama dengan kata-kata yang terdapat dalam judul naskah. Jika tidak memadai, dewan redaksi akan mengubahnya atas persetujuan penulis.

\section{Pendahuluan}

Pendahuluan yang ditulis tidak lebih dari 500 kata, harus menjelaskan isu-isu mutakhir yang mengarah pada pentingnya penelitian yang dilakukan, tujuan penelitian dinyatakan dengan jelas, dan menuliskan state of the art dari topik penelitiannya sehingga gambaran utama penelitiannya menjadi jelas bagi para pembaca. Namun, acuan pustaka dalam pendahuluan harus dibatasi karena bukan merupakan pembahasan awal.

\section{Materi dan Metode}

Materi dan metode penelitian harus dijelaskan secara terperinci pada bagian ini sehingga memungkinkan bagi peneliti lain untuk mengulang penelitian ini. Materi atau bahan yang digunakan tidak diperinci secara terpisah, melainkan harus terintegrasi dengan prosedur penelitian. Misalnya, .."responden diminta mengisi daftar pertanyaan menggunakan pensil 2B dan memilih satu dari tiga poster yang diperlihatkan oleh peneliti...", tidak perlu memerincinya seperti berikut: " Materi penelitian terdiri atas: daftar pertanyaan, pensil 2B, dan poster. Jika penelitian menggunakan produk berpemilik (seperti paten) untuk pembanding, produk dimaksud harus dituliskan dalam nama yang baku atau dituliskan merk dagangnya di dalam tanda kurung jika dianggap membantu memperjelas pemahaman pembaca, namun syaratnya harus mendapat izin tertulis dari pemilik produk dimaksud sebelum dipublikasikan. Model, tipe, merk, dan produsen peralatan yang digunakan dalam penelitian harus dijelaskan. Metode dan model analisis statistik harus jelas sehingga memungkinkan bagi peneliti lain untuk melakukan pengulangan.

Sistematika penulisannya diurutkan sebagai berikut: materi, rancangan percobaan dan perlakuan, prosedur pelaksanaan penelitian, analisis laboratorium, dan analisis statistik. Sistematika ini tidak kaku, dapat disesuaikan dengan ciri bidang keilmuan. Misalnya, untuk penelitian agribisnis yang tidak ada analisis laboratoriumnya, tidak perlu ada analisis laboratorium. Sebaliknya, subbagian lainnya dapat ditambahkan sesuai kebutuhan.

\section{Hasil dan Pembahasan}

Hasil penelitian, termasuk hasil analisis statistiknya dipaparkan secara terperinci dalam bagian ini. Ilustrasi, jika diperlukan dapat disajikan dalam bentuk tabel dan/atau gambar. Tabel dan gambar harus sederhana, informatif, mudah dipahami, dan mandiri, dalam arti tabel atau gambar dimaksud harus bisa menjelaskan kepada pembaca sehingga pembaca tidak harus membaca tulisannya untuk memahaminya. Hal yang sudah dijelaskan dalam tabel atau gambar tidak perlu diulang dalam tulisan. Tabel dan gambar dimuat pada halaman terpisah darik teks.

Hasil penelitian selanjutnya dibahas dengan cara membandingkannya dengan hasil penelitian pada topik serupa dari peneliti sebelumnya untuk mengungkap keajegannya (konsistensinya) apakah konsisten (sama) atau berbeda, lalu jelaskan alasan ilmiahnya atas hasil dimaksud secara lugas dan tuntas sehingga memperjelas posisi hasil penelitiannya. Selanjutnya, temuan hasil penelitian diungkapkan disertai kelebihan dan kelemahannya, jika ada. Ungkapan temuan hasil penelitian ini akan mempermudah dalam menyimpulkan hasil penelitian.

Data rataan perlakuan harus ditulis dengan galat bakunya (standard errors). Tingkat signifikansi statistik dapat dinyatakan dalam $\mathrm{P}<0,05, \mathrm{P}<0,01$, dan $\mathrm{P}<0,001$. Khusus pada tabel, tingkat signifikansi dimaksud, berturut-turut dapat ditulis dengan *, **, dan ${ }^{* * *}$ sedangkan pada tabel dan grafik, perbedaan antarperlakuan dapat ditunjukkan dengan huruf $a, b$ untuk $\mathrm{P}<0,05$ dan $\mathrm{A}$, B untuk $\mathrm{P}<0,01$.

\section{Kesimpulan dan Implikasi}

Kesimpulan memuat temuan hasil penelitian yang mencerminkan kebaruan, keorisinilan, kepioneran, keuniversalan, dan kontribusi ilmiah dalam pengembangan ilmu pengetahuan dan teknologi. Pernyataan dalam simpulan terbebas dari frasa atau istilah statistik, seperti " ..berpengaruh nyata $(\mathrm{P}<0,05) "$

Penulis harus menjelaskan implikasi hasil penelitiannya dalam pengembangan keilmuan, dan dampaknya terhadap lingkungan, sosial, budaya, 
ekonomi, politik, dan/atau hukum. Implikasi dipaparkan dalam bahasa yang sederhana agar pembaca noncendekia dapat memahaminya dengan mudah.

\section{Ucapan Terima Kasih}

Ucapan terima kasih hanya wajib ditulis jika penelitian didukung (biaya, sarana, tenaga) oleh instansi atau individu, atau penelaah sejawat jika naskahnya ditelaah sebelum dipublikasikan.

\section{Daftar Pustaka}

Penulis bertanggung jawab atas kebenaran semua sumber pustaka yang dirujuk dan dituliskan dalam Daftar Pustaka dan yang diacu dalam teks. Sumber pustaka sangat dianjurkan menggunakan terbitan terbaru (10 tahun terakhir), dan disajikan secara alfabet dan dituliskan menurut format nama tahun. Beberapa format dan contoh penulisannya antara lain:

Naskah jurnal atau abstrak. Format: Nama Penulis. Tahun. Judul. Nama Jurnal. Volume: Halaman. Contoh:

Rahmawati R, G Praditina dan RA Munjin. 2009. Model pelayanan rumah sakit berbasis karakteristik sosial ekonomi masyarakat untuk meningkatkan kepuasan pasien. Jurnal Humaniora. 1(1): 18-29.

Buku. Format: Nama Penulis atau Nama Editor atau Nama Lembaga. Tahun. Judul. Edisi, Nama Penerbit, Tempat Penerbitan. Contoh:

Roestamy M. 2011. Konsep-konsep hukum kepemilikan properti bagi asing (dihubungkan dengan hukum pertanahan). Edisi pertama. PT. Alumni. Bandung.

Bab buku atau proseding. Format: Nama Penulis. Tahun. Judul. Dalam: Judul buku atau proseding (Nama Editor). Volume: Halaman. Nama Penerbit, Tempat Penerbitan. Contoh:

Goulet D. 2000. Ethics, culture and development: livestock, poverty and quality of rural life. In: Livestock, ethics and quality of life (eds. Hodges, John and Han, In K). 131-154. CABI Publishing, New York, NY 10016, USA.

Laporan pada pertemuan ilmiah (konferensi, workshop, dll) yang tidak tercakup dalam buku atau proseding. Format: Nama Penulis. Tahun. Judul. Judul atau Nama Pertemuan Ilmiah, Tempat Pertemuan. Jumlah halaman. Contoh:

Jalal F. 2011. Tantangan dan peluang pendidikan di Indonesia. Orasi Ilmiah. Wisuda XXVI Sarjana dan Pascasarjana Universitas Djuanda, Bogor. 16 hal.

Tesis atau Disertasi. Format: Nama Penulis. Tahun. Judul. Tesis atau Disertasi. Nama Perguruan Tinggi, Tempat Perguruan Tinggi. Contoh:

Roestamy M. 2008. Kepastian hukum atas kepemilikan rumah dan bangunan gedung oleh investor asing dikaitkan dengan asas nasionalitas dalam sistem hukum pertanahan Indonesia. Disertasi. Program Studi Doktor Ilmu Hukum Fakultas Hukum Universitas Padjadjaran, Bandung.

Karya Ilmiah Lepas yang dimuat pada Website. Karya ilmiah lepas yang dimuat pada website hanya dapat digunakan jika literatur standard lainnya tidak tersedia. Format: Nama Penulis. Tahun. Judul. Diunduh tanggal-bulan-tahun dari http://.... Contoh:

Bryant P. 1999. Biodiversity and Conservation. Retrieved October 4, 1999 from http://darwin bio.uci.edu/ sustain/bio65/Titlpage.htm

\section{Penulisan Nama Penulis yang Diacu pada Teks}

Nama penulis yang diacu di dalam teks tidak diperkenankan menggunakan footnote. Jika jumlah penulis kurang dari tiga nama penulis ditulis semua, jika jumlah penulis tidak kurang dari tiga, hanya penulis utama yang ditulis dan diikuti dengan et al. Contoh: Syamsah (2010) menyimpulkan bahwa pajak dan zakat memiliki hubungan reduktif dan deduktabel. Parameter kualitas layanan puskesmas secara simultan mempengaruhi kepuasan pasien (Yuningsih dan Maulana 2010). Kekurangan dari kualitas pelayanan rumah sakit dapat diatasi apabila rumah sakit memperhatikan karakteristik pasien (Rahmawati et al. 2010). Tingkat kepuasan pasien menjadi indikator penting dalam mengukur kualitas pelayanan kesehatan (Yuningsih dan Maulana 2010; Rahmawati et al. 2010).

\section{Tabel}

Tabel harus dibuat sesederhana dan sesedikit mungkin, namun sekurang-kurangnya harus memuat dua baris data. Jika hanya ada satu baris data, maka penyajiannya harus menggunakan grafik. Garis horisontal tabel hanya boleh untuk mencirikan batas baris teratas (heading) dan garis terbawah dari badan tabel, sedangkan garis-garis kolom tabel tidak diperkenankan. Tabel dibuat dengan menggunakan fungsi tabel dalam program microsoft office word. Judul tabel harus ringkas, jelas, dan informatif, diberi nomor urut angka arab, huruf kapital hanya pada huruf pertama judul tabel kecuali beberapa nama diri, dan ditempatkan di atas badan tabel. Lazimnya, peubah disajikan dalam baris dan perlakuan disajikan pada kolom tabel. Keterangan tabel disajikan di bagian bawah badan tabel tanpa menuliskan kata keterangan. Di dalam teks, nomor tabel harus dirujuk, misalnya: kepribadian dalam pandangan Islam merupakan integrasi sistem kalbu, akal, dan nafsu (Tabel 1). Judul tabel, tabel dan keterangan tabel disajikan pada halaman tersendiri setelah Daftar Pustaka. Lebar tabel $80 \mathrm{~mm}$ atau $160 \mathrm{~mm}$. Jangan menyisipkan tabel pada bagian teks. Contoh Tabel lebar $80 \mathrm{~mm}$ : 
Table 1 Persentase distribusi daya fitrah nafsani dalam pembentukan kepribadian

\begin{tabular}{lccc}
\hline \multirow{2}{*}{$\begin{array}{l}\text { Daya fitrah } \\
\text { nafsani }\end{array}$} & \multicolumn{3}{c}{ Tingkat kepribadian (\%) } \\
\cline { 2 - 4 } & Muthmainnah & Lawwamah & Ammarah \\
\hline Kalbu & 55 & 30 & 15 \\
Akal & 30 & 40 & 30 \\
Nafsu & 15 & 30 & 55 \\
\hline
\end{tabular}

Format tabel diubahsuai dari Sulaiman H (2010) tanpa mengubah substansi.

\section{Gambar dan Grafik}

Gambar dan grafik dibuat dalam format JPEG dan hanya diperbolehkan jika data hasil penelitian tidak dapat disajikan dalam bentuk tabel. Grafik yang dibuat dengan program microsoft office excel harus diubahsuiakan menjadi format JPEG dengan kualitas gambar yang layak cetak. Ukuran lebar gambar adalah $80 \mathrm{~mm}$ atau $160 \mathrm{~mm}$. Judul gambar harus ringkas, jelas, dan informatif, diberi nomor urut angka arab, huruf kapital hanya pada huruf pertama judul gambar kecuali beberapa nama diri, dan ditempatkan di bagian bawah gambar. Contoh gambar berformat JPEG lebar $80 \mathrm{~mm}$ (Gambar 1).

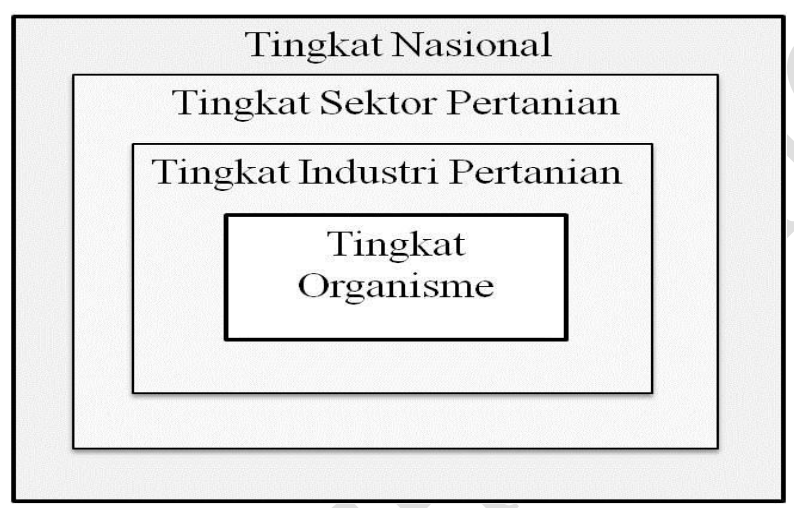

Gambar 1 Empat tingkat domain untuk menghadapi agroterorisme (ubahsuai dari Kohnen 2000).
Keterangan gambar ditulis setelah dan merupakan bagian integral dari judul gambar. Gambar dan judul gambar disajikan pada halaman tersendiri setelah halaman tabel. Di dalam teks, seluruh nomor gambar harus dirujuk secara berurutan seperti nomor tabel. Gambar dicetak hitam putih dan jika penulis menghendaki gambar berwarna, maka biaya pencetakan menjadi tanggung jawab penulis.

\section{Cetak Lepas}

Penulis yang naskahnya telah dipublikasikan akan mendapatkan satu Jurnal Humaniora dan dua eksemplar cetak lepas (reprint) artikelnya. Penulis yang ingin menambah jumlah jurnal dan cetak lepasnya dapat memesannya ke Dewan Redaksi melalui telefon atau email. Berikut ini adalah daftar harga Jurnal Humaniora dan cetak lepasnya, belum termasuk ongkos kirim.

Daftar harga Jurnal Humaniora dan cetak lepasnya

\begin{tabular}{lll}
\hline Jumlah & $\begin{array}{l}\text { Jurnal Syarikah } \\
\text { (Rp/eksemplar) }\end{array}$ & $\begin{array}{l}\text { Cetak lepasnya*) } \\
\text { (Rp/eksemplar) }\end{array}$ \\
\hline $1-5$ & 75.000 & 30.000 \\
6 atau lebih & 60.000 & 25.000 \\
\hline
\end{tabular}

${ }^{*}{ }^{6}$ pemesanan minimal 5 eksemplar. 


\section{SURAT PERNYATAAN ORISINALITAS ${ }^{1}$}

Kepada

\section{Dewan Editor Jurnal Syarikah}

Program Studi Ekonomi Islam Fakultas Ekonomi islam

Universitas Djuanda Bogor

Bersama ini kami mengajukan naskah,

\section{Judul :}

Penulis:

\begin{tabular}{|c|c|c|c|c|}
\hline No & $\begin{array}{c}\text { Penulis lengkap dengan } \\
\text { gelar akademik }\end{array}$ & Nama dan Alamat Institusi, email & $\begin{array}{l}\text { Tanda } \\
\text { Tangan }\end{array}$ & Tanggal \\
\hline
\end{tabular}

1

2

3

untuk dipublikasikan pada Jurnal Syarikah. Kami menyatakan bahwa naskah dimaksud adalah naskah orisinal hasil penelitian kami yang belum pernah dipublikasikan, tidak sedang dalam proses publikasi oleh media publikasi lainnya, tidak akan diajukan ke media publikasi lainnya selama dalam proses penelaahan (review) kecuali jika kami menarik secara resmi naskah dimaksud dari Dewan Redaksi Jurnal Syarikah, terbebas dari plagiarisme, dan kami bertanggung jawab atas seluruh substansi naskah berjudul tersebut di atas yang kami tulis.

Nama penulis untuk korespondensi:

Telepon/(hanya digunakan untuk keperluan korespondensi)

Email: (untuk keperluan korespondensi dan akan dicantumkan pada artikel yang

dipublikasikan)

Terima kasih atas perhatian dan kerjasamanya.

Tanggal:

Penulis:

Tanda tangan:

\footnotetext{
${ }^{1}$ Dikirim ke Dewan Redaksi Jurnal Syarikah, Program Studi Ekonomi Islam Fakultas Ekonomi Islam Universitas Djuanda Bogor, Gedung B Lantai IV Jl Tol Ciawi No. 1 Kotak Pos 35 Ciawi Bogor 16720, difaksimilikan ke 02518240985, dan hasil scanning-nya diemailkan ke Jurnal.Syarikah@unida.ac.id.
} 


\section{SURAT PERNYATAAN PEMINDAHAN HAK CIPTA ${ }^{2}$}

Yang bertanda tangan di bawah ini adalah penulis naskah yang berjudul:

yang diajukan untuk dipublikasikan pada Jurnal Syarikah: Jurnal Ekonomi Islam ISSN 2442-4420 menyatakan bahwa:

Kami bersedia memindahkan hak publikasi, distribusi, reproduksi, dan menjual naskah kamiyang berjudul tersebut di atas sebagai bagian dari Jurnal Syarikah kepada Dewan Redaksi Jurnal Syarikah ISSN 2442-4420

Demikian surat pernyataan ini saya buat dengan sadar, penuh rasa tanggung jawab, dan tanpa paksaan dari pihak mana pun!

\begin{tabular}{llcc}
\hline No & $\begin{array}{l}\text { Nama Penulis (lengkap } \\
\text { dengan gelar akademik) }\end{array}$
\end{tabular}$\quad$ Nama dan Alamat Institusi, email $\begin{gathered}\text { Tanda } \\
\text { Tangan }\end{gathered}$ Tanggal




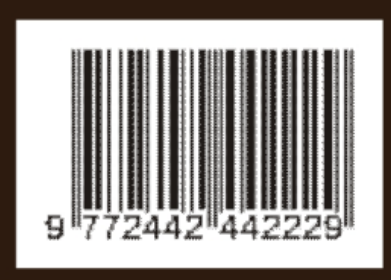

